\title{
IAMJ
}

INTERNATIONAL

AYURVEDIC

MEDICAL JOURNAL

Review Article

ISSN: 2320-5091

Impact Factor: 6.719

\section{A CONCEPTUAL STUDY ON YASHTIMADHU (GLYCYRRHIZA GLABRA) - A REVIEW ARTICLE}

\author{
Rekha Karveti $^{1}$, Shiromani Mishra ${ }^{2}$ \\ ${ }^{1}$ PG Scholar, PG Dept. of Dravyaguna, Govt. Auto. Dhanwantari Ayurveda College Ujjain Madhya Pradesh, \\ India \\ ${ }^{2}$ Guide \& Associate Professor, PG Dept. of Dravyaguna Govt. Auto. Dhanwantari Ayurveda College Ujjain, \\ Madhya Pradesh, India
}

Corresponding Author: karveti.rekha27@gmail.com

\section{https://doi.org/10.46607/iamj13p5062021}

(Published online: September 2021)

Open Access

(C) International Ayurvedic Medical Journal, India 2021

Article Received: 24/08/2021 - Peer Reviewed: 12/09/2021 - Accepted for Publication: 15/09/2021

Check for updates

\begin{abstract}
Yashtimadhu (Glycyrrhiza glabra), a powerful medicinal plant listed in Ayurveda, heals a wide range of ailments, from simple coughs to more serious illnesses including hepatitis and cancer. Glycyrrhizin, glycyrrhetine acid, glycyrrheic acid, asparagine, liquirtin, glabrine, A \& B, and flavonoids have all been identified as significant phytoconstituents. Anti-tussive, anti-inflammatory, anti-ulcer, antioxidant, antispasmodic, spasmodic, antibiotic, and antiviral medications are all available through the organisation. The important pharmacological actions are summarised in this article, with a focus on the role of flavonoids and isoflavonoids in pain relief. This might aid with future medical outcomes identification and development.
\end{abstract}

Keywords: Yashtimadhu, glycyrrhizin, Glycyrrhiza glabra etc.

\section{INTRODUCTION}

Ayurveda is an ancient medical science that focuses on disease diagnosis and treatment with natural medicines. In the Sanskrit language Yashtimadhu and the contemporary language Mulathi, Glycyrrhiza glabra is the name of the sweet healer. Liquorice was utilised as a remedy in many ancient cultures and is still a popular plant today [1]. It grows wild in many places 
across the world, including India, and even in subtropical and warm climates.

Glycyrrhize is derived from the ancient Greek term glycos, which means sweet. Rhizes, which means root, is derived from glycos. Medicinal plants contribute to the well-being of people and populations. The therapeutic benefit of these plants is found in chemical components that have physiological effects on the human body. Plants' most important bioactive chemicals are triterspenic saponin, flavonoids, tannins, alkaloids, and phenolic compounds.

\section{Aim \& Objectives}

To evaluate the effect of Yashtimadhu (Glycyrrhiza glabra) in human

\section{Methodology}

The information was gathered from a variety of sources, including papers, textbooks, Samhitas, the internet, and legitimate online sources.

\section{Geography}

Glycyrrhiza glabra, popularly known as liquorice or sweet wood, is a plant native to the Mediterranean and parts of Asia. In India, there are ecosystems in Jammu and Kashmir, Punjab, and the sub-Himalayan regions. Egyptians, Chinese, Greeks, Indians, and Romans all utilised the dried root of this plant as an expectorant and carminative in the past. ${ }^{[2]}$

\section{Morphologic Studies}

The Glycyrrhiza glabra linn is a little shrub that grows to a height of 2.5 metres. The leaves are complex, distorted, and have four to seven pairs of oblong, elliptical, or lanceolate leaves. The blooms are slender and papillon in appearance, with axilla spikes and a violet lavender scent. The calyx is tiny, bell-shaped, and has glandular hairs on the points. The fruit is a moderately reticulating, erect, glabrous plucked legume or pod with lengths of up to $1.5 \mathrm{~cm}$. 3-5 brown reniform seeds are generally seen in the fruit. The taproot is $1.5 \mathrm{~cm}$ in length and includes $3-5$ secondary roots. ${ }^{[3]}$ Classification

Kingdom: Plantae

Division: Angiospermae

Class: Dicotyledoneae

Order: Rosales

Family: Leguminosae
Genus: Glycyrrhiza

Species: glabra Linn

Binomial Name: Glycyrrhiza glabra L.

Properties of Yastimadhu ${ }^{[4]}$

Rasa:Madhura

Guna: Guru, Snigdha

Veerya: Sheeta

Vipaka: Madhura

Karma: Vatapittahara, Vranaropana, Sothahara, Vedanasthapana, Balavarnakara,

Chakshushyam, Trishnanigraha, Chardinigraha.

\section{Phytochemicals Constituents}

Glycyrrhizin, a saponin glycoside found in the roots of Glycyrrhiza glabra Linn, is the major active component, accounting for 10 to $25 \%$ of the licorice content. It contains 60 times the sweetness of cane sugar. Flavonoid-rich fractions include liquertin, isoliquertin, liquiritigenin, and rhamnoliquirilin, as well as five novel flavonoids identified from dried roots. A novel prenylated isoflavan counterpart, Kanzonol R, was also found. ${ }^{[5,6]}$

\section{Ayurvedic Uses}

Glycyrrhizin has been demonstrated to be beneficial in treating chronic hepatitis and liver cirrhosis. Glycyrrhiza glabra is one of the most effective remedies for pain and other ailments produced by caustic substances, such as gastrointestinal discomfort. It reduces the unpleasant effects of acids better than alkalies ${ }^{[7]}$ It's a fantastic tonic that can even help with genitourinary catarrh. According to the British Herbal Compendium, liquorice is used to treat bronchitis, chronic gastritis, peptic ulcer, rheumatism and arthritis, adrenal insufficiency, and liver toxicity. Stronger Neo-Minophagen C, a kind of glycyrrhizin, has been used in Japan for more than 60 years as a treatment for chronic hepatitis (SNMC). In clinical studies, it has also been utilised as an anti-allergic and anti-hepatitis agent. ${ }^{[8]}$ Topical formulations containing glycyrrhetinic acid are used to treat herpes, eczema, and psoriasis. [Image courtesy of Indian Medicinal Plants.] Its aspirin-like properties aid to reduce fevers and relieve aches and pains like headaches and stomach pain. Pharmacological actions: The Indian Herbal 
Pharmacopoeia recognises its usage as an anti-inflammatory and anti-ulcer agent. ${ }^{[9]}$

\section{Anti-Ulcerant}

DGL, a specific liquorice extract, can be used to treat peptic ulcers (deglycyrrhizinated liquorice). Glycyrrhiza glabra has an important role in the healing of Helicobacter pylori-related peptic ulcers. ${ }^{[10]}$

\section{Expectorant and Anti-Tussive}

It was observed that using liquorice powder and extract to treat sore throats, coughs, and bronchial catarrh proved effective. Its exact mechanism of operation is unknown. Irritability is relieved by liquorice, which also possesses expectorant effects. Carbaxolone, a semi-synthetic substance derived from Glycyrrhiza, stimulates gastric mucus production. Liquorice extract can cause mucus secretions in the trachea, which can cause demulcent and expectorant symptoms. ${ }^{[11]}$

\section{Anti-Inflammatory Effect}

Liquorice extract contains glycyrrhetinic acid, which has anti-inflammatory effects comparable to glucocorticoids and mineralocorticoids ${ }^{[12] . ~ C a r b e n o x o l o n e ~}$ (Biogastron), a glycyrrhetinic acid analogue, has been demonstrated to inhibit 15-hydroxyprostaglandin dehydrogenase and 13 prostaglandin, two enzymes involved in prostaglandin production, resulting in higher prostaglandin levels. Prostaglandins promote mucous secretion and cell growth. As a result, ulcer healing is aided. ${ }^{[13]}$

\section{Anti- Carcinogenic}

The PDQ cancer information review has current research on the use of PC-SPES as a dietary supplement in the management of persons with prostate cancer. PC-SPES is an eight-plant mix. Glycyrrhiza glabra is present in all of them. Human PSA and testosterone levels are reduced by PC-SPES, according to clinical research. ${ }^{[14]}$

\section{Hepatoprotective}

It is used to treat chronic hepatitis C. As a complementary and alternative medicine, Glycyrrhiza glabra showed significant alterations in virological and/or biochemical response. ${ }^{[15]}$

\section{Antimicrobial}

Due to the presence of secondary metabolites such saponins, alkaloids, and flavonoids, the hydro-methanolic root extract of Glycyrrhiza glabra shows high antibacterial action. ${ }^{[16]}$

\section{Memory Boosting}

The effects of Glycyrrhiza glabra on learning and memory in mice were investigated. An elevated plusmaze and a passive avoidance paradigm were used to evaluate learning and memory. The aqueous liquorice extract was administered in three dosages [75, 150, and $300 \mathrm{mg} / \mathrm{kg}$ p.o.]. For seven days, separate groups of animals were subjected to the experiment. Mice demonstrated considerable gains in learning and memory at a dose of $150 \mathrm{mg} / \mathrm{kg}$. However, the particular mechanism of action is unknown, necessitating more investigation. ${ }^{[17]}$

\section{Analgesic activity mode}

The plasma membrane of cells mediates a range of stimuli such as discomfort, hotness, and coldness, according to a paper on Anthocephalus chinensis (Lam), and the TRP and TRPV1 receptors on the cell membrane are responsible for pain transmission. TRPV1 antagonists, such as flavonoids and their equivalents found in Anthocephalus chinensis, block signalling through the cell membrane. ${ }^{[18]}$ Glycyrrhiza glabra also contains flavonoids and isoflavonoids.

\section{Toxicity and Side Effects}

Increased blood pressure is one of the most commonly reported negative effects of licorice supplementation due to its influence on the rennin-angiotensin-aldosterone pathway. The patient may also develop hypokalemia and salt retention, which can lead to edoema. When therapy is stopped, the symptoms usually fade away. ${ }^{[19]}$ There are no negative effects dur-

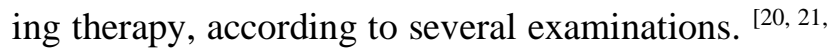
22]. The incidence and severity of symptoms are affected by specific sensitivity, as well as the amount and duration of licorice administration. Due to enterohepatic cycling, patients with a prolonged gastrointestinal processing time may be more susceptible to these adverse effects. Patients with mineral-corticoid overload syndromes consume between 1.5 and 250 grammes of liquorice every day. [22] 


\section{Dosing}

For most stable individuals, a standard dose of 1-10 mg glycyrrhizin, equivalent to 1-5 grammes of liquorice, has been shown to be helpful. ${ }^{[23]}$

\section{DISCUSSION}

Ayurveda is an ancient medical science, deals with the diagnosis of disease and its treatment with herbal and plant-based medicaments in the traditional system of medicine, the roots and rhizomes of Yashtimadhu have been in clinical use for centuries. The term Glycyrrhiza has been derived from the ancient Greek word glykos, meaning sweet and rhiza, meaning root ${ }^{\text {[24] }}$ Yashtimadhu consists of flavonoids, triterpene, amino acids, pectins, saponins, polysaccharides, simple sugars, mineral salts, and various other substances. Glycyrrhizin, a triterpenoid compound, accounts for the sweet taste of licorice root. These bioactive constituents contribute to the Yashtimadhu roots anti-inflammatory ${ }^{[25]}$ and antioxidant activity [26]

\section{CONCLUSION}

Yashtimadhu (Glycyrrhiza glabra Linn) is a major ethnopharmacological herb. The current research focuses on liquorice's pharmacological qualities, particularly it's capacity to reduce pain. Yashtimadhu tablet type is a good sort of drug to study for memory enhancement and memory impairment in youngsters. Furthermore, by isolating the active molecule, a detailed investigation is required to determine the specific mechanism of action as a potent and efficient neuroprotective agent. The findings will enable future research into the potential of Glycyrrhiza glabra Linn as a disease therapy.

\section{REFERENCES}

1. Sharma, AR (editor); Sutra Sthana. Sushruta Samhita of Maharshi Sushruta Varanasi. Chaukhamba Surbharati Prakashan, 2001; 42 (5): p. 45

2. http://www.divineremedies.com/glycyrrhiza_glabra.html (15/09/2009).

3. The Ayurvedic Pharmacopoeia of India: Ministry of Health and Family Welfare, Department of Health, Govt. of India, Volume - 1, 1st edition. p.127.
4. Misra B and Vaisya R., editors. Bhavaprakasa Samhita of Bhavamisra, 11thedition, Chaukhambha Sanskrit Sansthan, Varanasi, 2010; Vol-1: p.65.

5. Rastogi RP and Mehrotra BN. Compendium of Indian medicinal plants published by Central Drug Research Institute, Lucknow and National Institute of Sciences Communication and Information Resources, New Delhi, 1990-1994;

6. 395-398. 6. The Wealth of India, A Dictionary of Indian Raw Materials and Industrial Products, First Supplement series, published by National Institute of Sciences Communication and Information Resources, CSIR, New Delhi. 2005; Vol.3, D-1, 195-198.

7. Khare CP. Encyclopedia of Indian Medicinal Plants. Springer-Verlag, New York, 2004; 233-235.

8. Chopra RN, Chopra IC. Indigenous Drugs of India. Edn 2, Academic Publishers, Kolkata, 1958; 183-187.

9. Nadkarni KM. Indian Materia Medica, Popular Prakashan Pvt. Ltd.Mumbai, 1976; 582- 4.

10. Acharaya SK, Dasarathy S, Tandon A, Joshi YK, Tandon BN, (1993). Preliminary open trial on interferon stimulator (SNMC) derived from Glycyrrhiza glabra in the treatment of subacute hepatic failure. Ind. J. Med. Res. 98: 69-74.

11. Bennet A, Clark-Wibberley T, Stamford IF and Wright JE, Aspirin-induced gastric mucosal damage in rats: cimetidine and DGL together give great protection than low doses of either drug alone. Journal of Pharmacy and Pharmacology.1980; 32: 151.

12. Davood Mehrabani, Sara Japoni, Majid Edjtehadi, and Mehdi Saberi Firoozi. The healing effect of liquorice on Helicobacter pylori-infected peptic ulcers. Journal of Research in Medical Sciences, 2013 Jun; 18 (6): 532-533. http://www.ncbi.nlm.nih.gov/pmc/articles/PMC3818629/

13. Murray WJ. Herbal Medications for Gastrointestinal Problems, Herbal Medicinals- A Clinician's Guide, Pharmaceutical Products Press, New York, 1998; 7993.

14. Visavadiya NP, Soni B, Dalwadi N. Evaluation of antioxidant and anti-atherogenic properties of Glycyrrhiza glabra root using In vitro models. International Journal of Food Sciences and Nutrition, 2009; 60(2): 135-149.

15. Ahshawat MS, Saraf S, Saraf S. Preparation and characterization of herbal creams for improvement of skin viscoelastic properties. International Journal of Cosmetic Science, 2008; 30(3):183-193. 
16. Baker M E. Liquorice and enzymes other than 11- hydroxysteroid dehydrogenase: An evolutionary perspective, Steroids, 1994; 59:136-141.

17. http://www.ncbi.nlm.nih.gov/pubmedhealth/PMH0032816/, PDQ Cancer Information Summaries [Internet], Published online: January 7, 2015.

18. Roy SD, Karmakar PR, Dash S, Chakraborty J, Das B. Hair growth stimulating effect and phytochemical evaluation of hydro-alcoholic extract of Glycyrrhiza glabra, Global J res Med Plants \& Indigen Med, 2014; 3(2): 40-47.

19. Dodoala Sujatha et al., Amelioration of chronic pain by Anthocephalus chinensis(Lam) extract is mediated through TRPV1 receptors, NIPER, Hyderabad, India. Available from: https://bps.conference-services.net/resources/344/3811/pdf/PHARM14_0227.pdf.

20. Van Rossum TG, Vulto AG, Hop WC, Schalm SW, (2001). Glycyrrhizin induced reduction of ALT in European patients with chronic hepatitis C. Am J Gastroenterol. 96: 2432-2437.

21. Tsubota A, Kumada H, Arase Y, et al (1999). Combined ursodeoxycholic acid and glycyrrhizin therapy for chronic hepatitis $\mathrm{C}$ virus infection: a randomized controlled trial in 170 patients. Eur J Gastroenterol Hepatol. 11: 1077-1083.

22. Walker BR, Edwards CR. Liquorice induced hypertension and syndromes of apparent mineralocorticoid excess. Endocrinologyand Metabolism clinics of North America, 1994; 23: 359-377.

23. Sri Jyothsna P. M., Santosh Kumar Verma, M. Sreevani, Bandana Singh, A Review On Yashtimadhu (Glycyrrhiza glabra) - AnExcellent Medicinal Plant For The Future, World Journal Of Pharmaceutical Research, sjif Impact Factor 6.805, Volume 6, Issue 1, 261-269, Issn 2277-7105.

24. . Lakshmi T and Geetha RV, Glycyrrhiza glabra Linn commonly known as licorice: A Therapeutic review. Int J Pharm Pharm Sci, 2011; 3: 20-25.

25. Yokota T, Nishio H, Kubota Y and Mizoguchi M. The inhibitory effect of glabridin from liquorice extracts on melanogenesis and inflammation. Pigm Cell Res, 1998; 11: 355-361.

26. u HS, Li XJ, Zhao BL, Han ZW and Xin WJ, Effects of Glycyrrhiza flavonoid on lipid peroxidation and active oxygen radicals. Yao Xue Xue Bao, 1989; 24: 807-12.

\section{Source of Support: Nil Conflict of Interest: None Declared}

How to cite this URL: Rekha Karveti \& Shiromani Mishra: A Conceptual Study On Yashtimadhu (Glycyrrhiza Glabra) - A Review Article. International Ayurvedic Medical Journal \{online\} 2021 \{cited September 2021\} Available from: http://www.iamj.in/posts/images/upload/3130_3134.pdf 